\title{
BIOLOGIJA I EKOLOGIJA BIJELE LOBODE (Chenopodium album L.)
}

\author{
BIOLOGY AND ECOLOGY OF COMMON LAMBSQUARTERS \\ (Chenopodium album L.)
}

\author{
Ema Brijačak, Valentina Šoštarčić, Maja Šćepanović
}

\section{SAŽETAK}

Bijela loboda (Chenopodium album L.) jednogodišnji je širokolisni korov iz porodice lobodnjača (Chenopodiaceae). Podnosi vrlo različite klimatske uvjete i različite tipove tala zbog čega se ubraja među pet najrasprostranjenijih korovnih biljaka u svijetu. U Hrvatskoj je treći najučestaliji korov okopavinskih usjeva. Loboda je kozmopolitska vrsta $\mathrm{s}$ arealom rasprostranjenosti od $70^{\circ}$ sjeverne do $50^{\circ}$ južne geografske širine. Sposobna je prilagoditi se različitim klimatskim uvjetima pa biološki temperaturni minimum $\left(\mathrm{T}_{\mathrm{b}}\right)$, ovisno o klimatu, varira od 2,0 do $6,0^{\circ} \mathrm{C}$. Za područje kontinentalne Hrvatske $T_{b}$ iznosi $3,4^{\circ} \mathrm{C}$. Može nicati u uvjetima visokog vodnog stresa kao i u širokom rasponu $\mathrm{pH}$ tla vrijednosti od jako kiselih do alkalnih. Svojom prisutnošću u usjevu, ovisno o vremenu nicanja, gustoći i razvojnom stadiju kulture, znatno utječe na prinos okopavinskih kao i povrtlarskih kultura. Važan je korov u oko 40 poljoprivrednih kultura, a najčešće u šećernoj repi, krumpiru, soji, kukuruzu, suncokretu i jarim žitaricama. Glavna štetnost lobode, ogleda se u direktnim štetama. Važne su i indirektne štete kao npr. otežana žetva, kontaminacija uroda i tla sjemenjem, prenošenje virusnih bolesti na kultivirano bilje i dr. Pelud bijele lobode kod osjetljivih ljudi uzrokuje jake alergijske reakcije.

Ključne riječi: bijela loboda, morfologija, biologija, ekologija, vrijeme nicanja

\section{ABSTRACT}

Common lamb's quarters (Chenopodium album L.) is a annual broadleaf weed from the Chenopodiaceae family. This species tolerates very different climatic conditions and types of soils, which is why it is ranked among the five most frequent weeds in the world. In Croatia, it is ranked as the third most common weed in row crops. Common lamb'squarters is a cosmopolitan species with a widespread area from $70^{\circ}$ north to $50^{\circ}$ south latitude. It is capable of adapting to different climatic conditions therefore the basic temperature varies worlwide from 
2.0 to $6.0{ }^{\circ} \mathrm{C}$, while for the continental Croatia it is $3.4{ }^{\circ} \mathrm{C}$. It can sprout under high water stress conditions as well as in a wide range of $\mathrm{pH}$ soils from very acid to alkaline soils. Depending on the density, time of emergence and development stage of crop, it significantly affects the reduction of potential yield of row and some vegetable crops. It is troublesome weed in about 40 agricultural crops, and it can be most commonly found in sugar cane, potato, corn and spring cereals. The main damage of common lamb's quarters, as well as in other weeds, is reflected in direct damage or reduced yield of cultivated crops. There are also significant indirect damages caused by lamb's quarters among which are the most significant summer allergic reactions caused by pollen.

Keywords: common lambsquarters, morphology, biology, ecology, emergence time

\section{UVOD}

Chenopodium album L. (CHEAL) ${ }^{1}$ je jednogodišnja biljna vrsta iz porodice Chenopodiaceae koja obuhvaća veći broj kultiviranih, ali i korovnih biljaka. Šulek (1879.) u Jugoslavenskom imeniku bilja navodi nekoliko narodnih naziva za ovu vrstu: pepeljuga, guščja noga, kenopot i svinjska smrt. Ostojić i sur. (1991.) navode ostale narodne nazive: jurčica, jurčica bijela, jurčica prahnasta i jurjevac. Autor također navodi da naš poznati lingvist P. Skok lobodu svrstava u biljku sveslavenskog i praslavenskog porijekla. Naziv su posudili Mađari i Rumunji - loboda i Arbanasi - lebote. Prema istom autoru, Slovenci je nazivaju bela metlika, a Makedonci pepeljasta loboda. U engleskom govornom području poznat je kao lamb's quarters, melde, goosefoot i fat-hen. Ime roda je izvedeno od grčke riječi "chen" što znači guska i latinske riječi "podium" što znači stopalo. Ime vrste, album (bijelo), odnosi se na bijelo-sive zrnate kapljice voska koje se nalaze na naličju listova (Jellen i sur., 2011.).

Chenopodium album ima vrlo složenu taksonomiju te je podijeljen $\mathrm{u}$ brojne podvrste $\mathrm{i}$ varijetete, međutim razlike među njima su vrlo teško uočljive. Podvrste Chenopodium album subsp. album, Chenopodium album subsp. striatum Murr., Chenopodium album var. reticulatum Uotila su opisane u enciklopediji biljaka Flora europaea ${ }^{2}$. U svijetu razlikujemo morfološki i fiziološki različite biotipove vrste Chenopodium album. Različitost biotipova posljedica je seksualne reprodukcije i rekombinacije gena. U literaturi se biotipovi nazivaju i sinonimima vrste Chenopodium album, a oni su C. album var. microphyllum, C. album var. stevensii,

\footnotetext{
${ }^{1}$ https://gd.eppo.int/taxon/CHEAL, pristupljeno 16. siječnja 2018.

${ }^{2}$ http://rbg-web2.rbge.org.uk, pristupljeno 16. siječnja 2018.
} 
C. acerifolium, C. centrorubrum, C. giganteum, C. jenissejense, C. lanceolatum, C. pedunculare i C. probstii. Chenopodium album se također križa s nekoliko vrsta iz ovoga roda kao što su $C$. berlandieri, C. ficifolium, C. opulifolium, C. strictum i C. suecicum ${ }^{3}$.

Nekada se smatralo da vrsta Chenopodium album potječe iz Europe. Međutim, nedavna arheološka istraživanja pokazuju da su Američki Indijanci sakupljali i koristili sjeme ove vrste tijekom 16. stoljeća, dakle prije dolaska europske kulture i trgovine do Novoga svijeta. Vjeruje se da je sjeme bijele lobode bilo korišteno za prehranu još u prapovijesti ${ }^{4}$. Jedinke vrste Chenopodium album nalaze se i na nadmorskim visinama do $3600 \mathrm{~m}$, dok se areal rasprostranjenosti vrste kreće od $70^{\circ}$ sjeverne pa sve do $50^{\circ}$ južne geografske širine (slika 1). Loboda podnosi vrlo različite klimatske uvjete i različite tipove tala zbog čega je Coquilat (1951.) svrstava među pet najrasprostranjenijih biljaka u svijetu. Jedan je od glavnih korova Kanade i Europe, dok je u Indiji, Meksiku, Novom Zelandu, Pakistanu i Južnoj Americi rangiran kao jedan od šest najopasnijih korova (Holm i sur., 1977.). Da je loboda veoma važan korov u Hrvatskoj potvrđuje i Ostojić (2011.), koji na osnovi 165 poljskih pokusa provedenih u okopavinama u razdoblju 1969.-2009. utvrđuje prisutnost lobode na $71 \%$ lokacija čime ju svrstava na treće mjesto po zastupljenosti u okopavinskim usjevima kontinentalne Hrvatske.

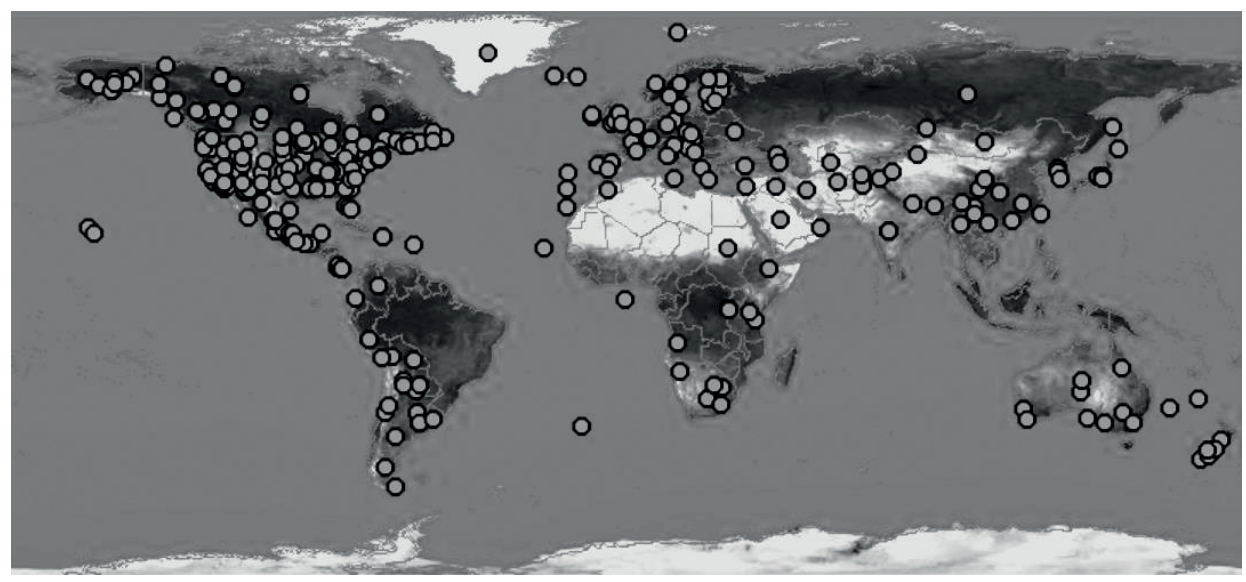

Slika 1. Areal rasprostranjenosti vrste Chenopodium album (izvor: http://www.discoverlife.org/)

Picture 1 Distribution area of species Chenopodium album

\footnotetext{
${ }^{3} \mathrm{https} / / /$ en.wikipedia.org/wiki/Chenopodium_album, pristupljeno 16. siječnja 2018.

${ }^{4}$ https://plants.ces.ncsu.edu/plants/all/chenopodium-album/, pristupljeno 16. siječnja 2018.
} 
Ema Brijačak i sur.: Biologija i ekologija bijele lobode (Chenopodium album L.)

Chenopodium album je uobičajeni korov gotovo svih kultiviranih usjeva, vrtova, hortikulturnih usjeva i trajnih nasada. Nalazi se i na pustopoljinama, na pašnjacima i neobrađenim zemljištima, uz puteve i riječne obale. Najbolje se razvija na plodnim, teškim i dobro navodnjavanim tlima (može se razviti i do $2 \mathrm{~m} \mathrm{u}$ visinu), dok na sušnim i manje plodnim tlima ima znatno manji rast (patuljasti). Česti je korov u oko 40 poljoprivrednih kultura, a najčešće ga se može pronaći u šećernoj repi, krumpiru, kukuruzu i jarim žitaricama. U Hrvatskoj se naročito često javlja na repištima (Ostojić i sur., 1991.). Američki istraživač Dowson (1985.) navodi da je zbog nižih zahtjeva za toplinom vrsta Chenopodium album sposobna otpočeti nicanje ranije te zbog toga nanosi šećernoj repi najveće štete u razdoblju između 3. i 9. tjedna iza nicanja. Na proizvodnom području Viro tvornice šećera Virovitica i Sladorane Županja na 16 lokacija obavljeno je sustavno praćenje korovne flore i inventarizacija korova te je utvrđena dominacija lobode na svim lokacijama. Anketirani proizvođači šećerne repe $\mathrm{s}$ tog područja također navode lobodu kao glavni korovni problem u šećernoj repi (Barić i Šćepanović, 2015.). Na Himalajama se bijela loboda uzgaja kao ratarska kultura, dok se u Indiji uzgaja kao tradicionalno zeljasto povrće (Jansen, 2004.).

Glavna štetnost lobode, kao i kod drugih korova, ogleda se u direktnim štetama, odnosno redukciji prinosa uzgajanih kultura. U poljskim pokusima u Kanadi utvrđeno je da $\mathrm{s}$ gustoćom od 172 do 300 biljaka $\mathrm{m}^{-2}$ Chenopodium album može uzrokovati gubitak prinosa kukuruza između 6 i 58\% (Sibuga i Bandeen, 1980; Ngouajio i sur., 1999.). U Španjolskoj su Torner i sur. (1995.) zabilježili gubitak prinosa od $22,3 \%$ na navodnjavanim poljskim pokusima kad se kukuruz nadmetao s bijelom lobodom jednake gustoće. S gustoćom od 1,6 biljaka bijele lobode na dužinskom metru međurednog prostora soje, Shurtleff i Coble (1985.) u Sjevernoj Karolini utvrdili su gubitak od 15\%. U Nizozemskoj je zabilježen gubitak prinosa šećerne repe od čak 93\% uzrokovan prisutnošću bijele lobode (Kropff i Spitters, 1991; Kropff i sur., 1992.). Iako gubitci prinosa uzrokovani ovom vrstom variraju ovisno o usjevu, gustoći i lokaciji, u svim navedenim slučajevima gubitci su bili od velike ekonomske važnosti. Utvrđeno je također da bijela loboda ima alelopatski učinak na kultivirane biljke kao što su kukuruz, soja, mrkva, krastavci, luk, rajčica, suncokret, salata i zob (Bhowmik, 1982; Reinhard i sur., 1994). Tako je u SAD-u utvrđeno da biljni ostatci ove vrste u poljskim uvjetima mogu uzrokovati umanjeni rast kukuruza i soje od 15-30\% (Bhowmik i Doll, 1980.) i gubitak prinosa soje od 16-20\% u staklenicima (Bhowmik, 1982.). U laboratorijskim i plasteničkim istraživanjima provedenim u Južnoj Africi, Reinhardt i sur. (1994.) utvrdili su smetnje u rastu 
Ema Brijačak i sur.: Biologija i ekologija bijele lobode (Chenopodium album L.)

biljne mase od 68, 85, 47 i 51\% uzrokovane ostatcima vrste Chenopodium album na krastavcima, luku, rajčici i suncokretu. Dodatno, sitno sjeme ove vrste često je kontaminent tijekom žetve čime uzrokuje velike gubitke u kvaliteti i vrijednosti žitarica (Holm i sur., 1977.). Također, u slučaju konzumacije većih količina biljne mase ove vrste, uočeni su simptomi trovanja ovaca i svinja što (Buck i sur. 1966.) tumače prisustvom oksalne kiseline. Indirektne štete od lobode ogledaju se i u pojavi ljetne alergijske reakcije uzrokovane alergenom peludi ove biljne vrste (Wodehouse, 1971.).

U posljednja tri desetljeća pojava rezistentnih korova na herbicide postao je veliki problem. Vrsta Chenopodium album razvila je rezistentnost na nekoliko djelatnih tvari kao što su triazini, bromoksinil i pirazon (Solymosi i sur., 1986.). Rezistentni biotipovi ove vrste utvrđeni su u mnogim zemljama uključujući Belgiju, Bugarsku, Kanadu, Čile, Češku Republiku, Italiju, Francusku, Njemačku, Novi Zeland, Norvešku, Poljsku, Sloveniju, Španjolsku, Švicarsku, Nizozemsku, Ujedinjeno Kraljevstvo i $\mathrm{SAD}^{5}$, ali i u našoj zemlji (Flegar i Ostojić, 1993.). Prvu potvrdu rezistentnosti lobode na triazine u Hrvatskoj utvrdili su stručnjaci Instituta za zaštitu bilja Poljoprivrednog fakulteta Sveučilišta u Zagrebu (Ostojić i sur. 1983; Ostojić i Barić, 2017.). Naime, nakon višegodišnje primjene triazinskih preparata u bjelovarskoj regiji, na pojedinim kukuruzištima tretiranim pripravcima na osnovi atrazina, u proljeće 1982. uočen je izostanak djelovanja na lobodu. U novije vrijeme utvrđena je rezistentnost ove vrste na herbicide iz skupine ALS-inhibitora (Konstantinović i sur., 2015; Lowell i sur., 1996.) što je posljedica česte uporabe herbicida (sulfonilureja, imidazolinoni i triazolopirmidini) navedenog mehanizma djelovanja. Rezistentnost bijele lobode na herbicide ima značajan ekonomski utjecaj na poljoprivrednu proizvodnju. Rezistentni biotipovi kompeticijom uzrokuju direktne gubitke, osobito u proizvodnji bez obrade tla gdje je zbog pristupa ograničen izbor herbicida. Suzbijanje rezistentnih biotipova zahtijeva uporabu alternativnih herbicida ili integrirano upravljanje sustavom koji uključuje kombinaciju herbicida s nekemijskim metodama (Hagood, 1989.).

\section{MORFOLOŠKA OBILJEŽJA BIJELE LOBODE}

Chenopodium album razvija kratak razgranat korijen. Kotiledoni ove vrste su dugi, ovalni i nalaze se na hipokotilu crvenkaste boje (slika 2). Već u ovoj ranoj razvojnoj fazi površina kotiledona je posuta bjelkastom prevlakom, iako

\footnotetext{
${ }^{5}$ http://www.weedscience.org/Resistance/resistmodule.asp., pristupljeno 16. siječnja 2018
} 
značajno manje nego na prvim pravim i ostalim listovima. To je i glavni razlog zašto je suzbijanje lobode učinkovitije u ranoj razvojnoj fazi. Kotiledoni lobode su lancetastog oblika 8 - 10 (12) mm dugački i 1,5 - 2,0 (3,0) mm široki, pri vrhu tupi, dok se pri osnovi sužavaju u kratku dršku. S gornje strane kotiledoni su tamnozeleni, a s donje intenzivno crveno-ljubičaste boje (Kojić, 1981.). Oblik i boja kotiledona lobode, mogu dovesti do zamjene ove vrste s vrstom Amaranthus retroflexus L. (oštrodlakavi šćir). Razlika između ove dvije vrste vidljiva je kod rasta prvih pravih listova. Naime, kao što je vidljivo na slici 2. prvi pravi listovi lobode imaju nasuprotan rast. Nasuprotan rast podrazumijeva da prvi i drugi list rastu istovremeno, što je suprotno naizmjeničnom rasporedu listova šćira koji prvo razvija prvi list, a tek onda drugi pravi list (slika 3).

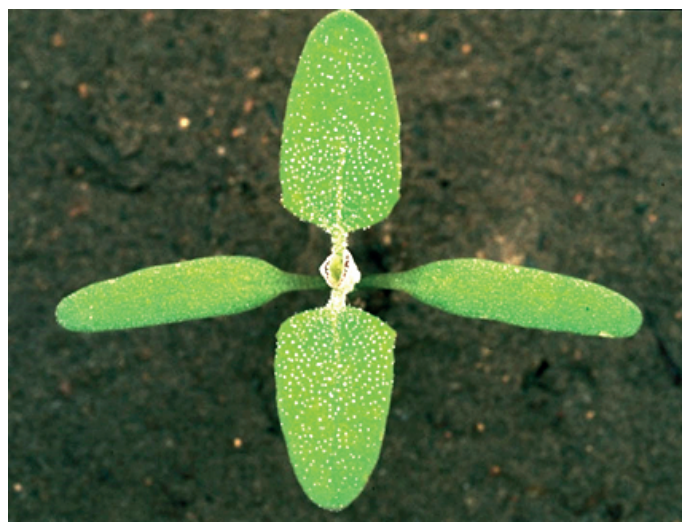

Slika 2. Kotiledoni bijele lobode Izvor: Š́epanović, $M$.

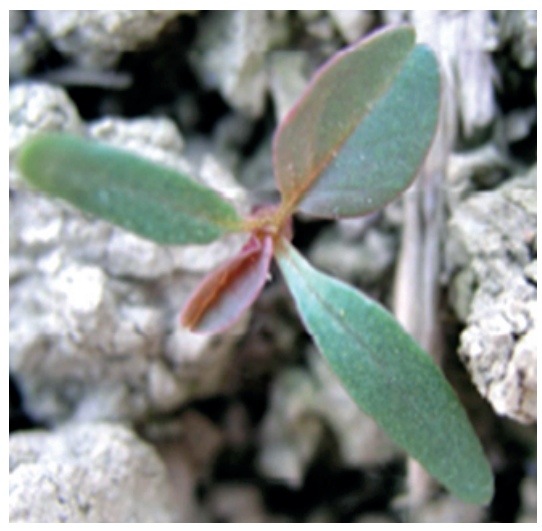

Slika 3. Kotiledoni oštrodlakavog šćira Izvor: Śćepanović, $M$

Picture 3 Seedlings of redroot pigweed

Picture 2 Seedlings of common lambsquarters

Stabljika lobode je uspravna, glatka, razgranata, uzduž užlijebljena, svjetlozelena, mjestimično crvenkasta. U povoljnim uvjetima ova vrsta može narasti čak do 2,5 m (Basset i Crompton, 1978.) (slika 4). Listovi su svijetli ili tamnozeleni, ovalnokopljasti do oblika romba, djelomično ili po čitavom rubu nazubljeni. S gornje strane su posuti brašnastim prahom zbog čega se u narodu i naziva pepeljuga. Listovi su izmjenični ili nasuprotni, a kad alterniraju, zavojiti su ili rijetko distihni, a samo ponekad grade rozete i polurozete (Nikolić, 2013.). Veličina lista kreće se od 1 do $12 \mathrm{~cm}$ u dužinu i 0,5 - 0,8 cm u širinu. Cvjetni omotač lobode je ujedinjen, stegnut i približno ograđuje odrasli plod (Everist, 1979). Cvjetovi su sitni i neugledni, zelenkaste boje obično smješteni u složenim cvatovima u prividnim štitovima ili metlicama. Razviju se vršno na bočnim granama ili u pazuhu vršnih listova. Ista jedinka može nositi i dvospolne i jednospolne ženske cvjetove unutar istog cvata (Nikolić, 2013.). 
Loboda je primarno biljka kratkog dana jer se vegetativna faza razvija u uvjetima dugog dana, a generativna (cvijet) u uvjetima kratkog dana, od lipnja do srpnja. Ipak, ovisno o okolišnim čimbenicima i vremenu nicanja generativnu fazu također može razviti u uvjetima dugog dana.

Plod je jednosjemeni oraščić. Biljka donese 200 - 2000 (3000) sjemenki. Sjeme dozrijeva od kolovoza pa sve do listopada odnosno sve do pojave prvih mrazeva. Dimenzije sjemenki lobode u prosjeku su širine $1,2 \mathrm{~mm}$, a dužine 1,3 mm (Basset i Crompton, 1978.), dok masa 1000 sjemenki iznosi svega 0,3 grama (Lemić i sur., 2014.)

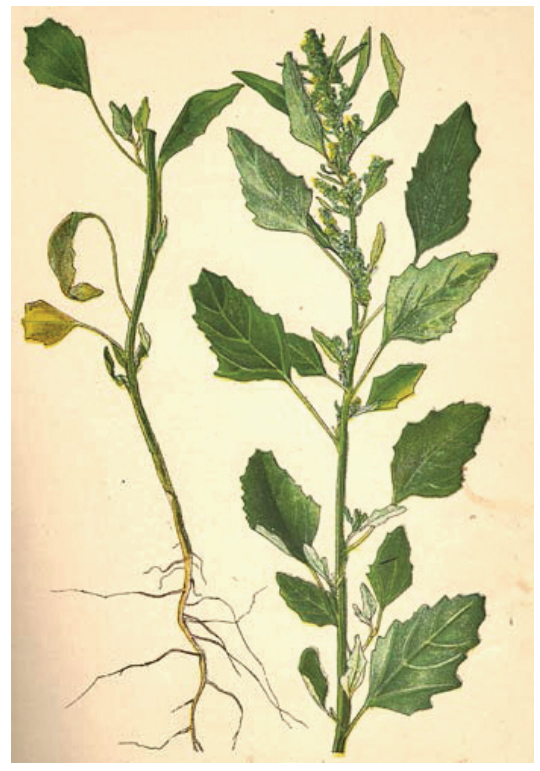

Slika 4. Odrasla biljka (izvor: www.agroatlas.ru)

Picture 4 Full-grown plant

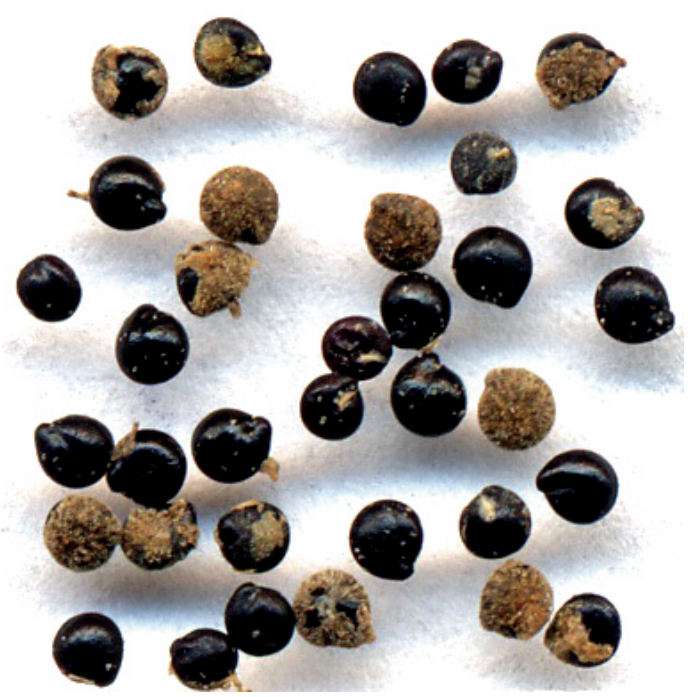

Slika 5. Polimorfno sjeme lobode (izvor: http://www.onlyfoods.net)

Picture 5 Polymorphic seeds of common lambsquarters

\section{MORFOLOŠKA OBILJEŽJA LOBODE VAŽNA ZA UČINAK MJERA SUZBIJANJA}

Uz preventivne mjere (sprječavanje osjemenjivanja), za suzbijanje lobode $u$ vegetaciji najviše se koriste kemijske mjere - primjena herbicidnih sredstava. Ipak je važno naglasiti, kako za razliku od nekih drugih korovnih vrsta (npr. ambrozija) koje su relativno neosjetljive na košnju stvarajući postrane grane iznad mjesta košnje, biljke lobode ukoliko se mehanički odstrane u ranoj razvojnoj fazi neće preživjeti. Poznato je da se osjetljivost korova na herbicide smanjuje njihovim 
ulaskom u kasnije razvojne stadije. To je posebice važno kod vrsta koje poput lobode na listovima razvijaju morfološke barijere (vosak) koje priječe ulaz herbicida. Mikromorfologija lisne površine važan je čimbenik koji utječe na depoziciju i usvajanje kapljica herbicida (Gudin i sur., 1976.). Najvažnije morfološke barijere ulasku herbicida su epikutikularni vosak, kutin, pektin, broj puči, dlaka i dr. (Hess, 1985.). U ranijim razvojnim fazama ove barijere su manje zastupljene pa je i olakšano suzbijanje lobode čak i primjenom umanjenih doza herbicida. Naime, Barić i sur. (2014.) navode da višekratna primjena umanjenih količina herbicida bolje suzbija korove u ranom stadiju razvoja nego što propisana (puna) doza suzbija odraslije (veće) korove. Dodatni razlog boljeg učinka herbicida u ranoj razvojnoj fazi je broj puči na listu. Utvrđeno je, da je broj puči po mm lisne površine lobode veći na mlađim nego na starijim listovima. Istraživanjima je također dokazano da loboda na površini listova nema razvijene žljezde, ali ima kuglaste dlake i to na licu i naličju lista. Međutim, za apsorpciju herbicida najvažniji su epikutikularni voskovi. Upravo je za ovu vrstu utvrđen značajan sadržaj epikutikularnih voskova $\left(274,5 \mu \mathrm{g} \mathrm{cm}^{-2}\right)$ što je primjerice skoro dvostruko više od portulaka (Portulaca oleracea) i čak 2,7 puta više nego na površini lista europskog mračnjaka (Abutilon theophsrasti). Naime, sadržaj epikutikularnih voskova na listovima drugih korovnih vrsta kreće se od 10 do $200 \mu \mathrm{g} \mathrm{cm}$ (McWhorter, 1993.). Ovaj podatak jasno ukazuje na otežano usvajanje herbicida kod ove korovne vrste. Zbog manjeg broja puči kao i većeg sadržaja epikutikulatrnih voskova na starijem lišću, bolji učinak primijenjenih herbicida ostvaruje se u ranijoj razvojnoj fazi lobode (slika 2.)

\section{BIOLOGIJA I EKOLOGIJA BIJELE LOBODE}

$\mathrm{S}$ fiziološkog gledišta, odnosno načina na koji obavlja fotosintezu Chenopodium album pripada skupini $\mathrm{C}_{3}$ biljnih vrsta. Prema Raunkierovoj klasifikaciji (1905.) pripada skupini terofitnih biljaka (Th), što znači da loboda nepovoljne uvjete preživljava u obliku sjemena koje joj služi za širenje i razmnožavanje (Uchytil, 1992.). Kao jednogodišnja biljna vrsta, bijela loboda se razmnožava isključivo sjemenom. Jedinke ove vrste pokazuju izrazito veliku plastičnost kao odgovor na njihovu edafsku i biotičku okolinu, a proizvodnja sjemena uvelike varira ovisno o tim čimbenicima. Prosječna proizvodnja sjemena varira između 3000 i 20000 sjemena/biljci (Korsmo i sur., 1981.), iako je na nekim jedinkama lobode (biljke soliteri) utvrđeno čak 50000 70000 sjemenki (Mandal, 1990.). Proizvodnja sjemena po jednoj biljci jako je ovisna o uvjetima u kojima ova vrsta raste. Zasigurno će rast u povoljnijim uvjetima, u uvjetima ranijeg ponika lobode te nedostatku kompeticije s ostalim biljnim vrstama favorizirati veću brojnost sjemenki po jedinki lobode i obrnuto. 
Sjemenke lobode se šire uglavnom antropozohorijom, odnosno epihorijom. U priobalnom području vodenih sustava sjemenke lobode se lijepe pomoću blata za ptice i druge životinje i tako se šire. Sjemenke su polimorfne što znači da se na istoj jedinci sjemenke mogu morfološki i fiziološki razlikovati. Polimorfne sjemenke se razlikuju po boji, masi i obliku kao i načinu otpuštanja s majčinske biljke (Baker i O'Dowd, 1982.). Većina sjemenki lobode je crne boje, međutim, postoje i sjemenke smeđe boje (slika 5), a mogu biti glatke ili hrapave površine (Harper i sur., 1965.). Pojava smeđih sjemenki s većom masom i tankom sjemenom ovojnicom je rezultat uvjeta kratkog dana tijekom formiranja sjemenki dok je stvaranje malih, crnih sjemenki s debljom sjemenom ovojnicom rezultat cvatnje u uvjetima dugog dana. Osim u boji, ove sjemenke se razlikuju i u dormantnosti jer su crne dormantne, a smeđe sjemenke kliju odmah nakon zriobe (Cumming, 1963.). Dormantnost kod lobode genetički je uzrokovana. Sjemenke su sposobne proklijati i 20 godina nakon što dospiju u tlo (Wright, 1972.). Već u vrijeme odvajanja od majčinske biljke sjemenke lobode su primarno dormantne zbog visokog sadržaja različitih inhibitora u sjemenci i nepropusne sjemene ovojnice (Šera i sur., 2009.). Istraživanjima je utvrđeno da svježe prikupljene sjemenke lobode pokazuju približno $35 \%$ klijavosti. Nisko-temperaturni tretmani između $0^{\circ} \mathrm{C}$ i $5^{\circ} \mathrm{C}$ povećavaju klijavost, kao i izlaganje sjemena naizmjence niskim i visokim temperaturama, stratifikacija i produljeno natapanje sjemena tijekom 20 dana. Sjemenke sporo kliju nakon suhog, unutarnjeg skladištenja, dok sjemenke koje su prezimjele u polju brzo prokliju kad se za to stvore optimalni uvjeti (Fryer i Makepeace, 1977.). Laboratorijskim istraživanjima utvrđena je najbolja klijavost lobode pri tretmanima stratifikacije sjemena uz dodatak $0,2 \%$-tne otopine $\mathrm{KNO}_{3}$, potapanjem sjemena u $77 \%$-tnu $\mathrm{H}_{2} \mathrm{SO}_{4}$ u trajanju od 5 minuta $(62,7 \%)$, te potapanjem sjemena u $2 \%$-tnu otopinu tiouree (Lemić i sur., 2014.).

Dolaskom u tlo, sjemenke poprimaju sekundarnu dormantnost ukoliko u tlu vladaju nepovoljni uvjeti za klijanje. Dubina položenog sjemena u tlu, značajno određuje nicanje lobode. S obzirom da je riječ o sitnosjemenoj vrsti, sjeme je sposobno poniknuti samo ako se nalazi u plitkom površinskom sloju tla. Već pri dubini od $6 \mathrm{~cm}$ nicanje lobode se značajno smanjuje (Benvenuti i sur., 2001; Kovačić, 2013.). Nicanje je, stoga, značajno uvjetovano agrotehničkim mjerama koje se provode na određenoj površini. Schweizer i Zimdahl (1984.) su tako šestogodišnjom integriranom proizvodnjom reducirali banku sjemena lobode $u$ tlu na samo 1 i $6 \%$ od ukupne populacije sjemenki.

Sjeme lobode može uspješno nicati u vrlo širokom rasponu $\mathrm{pH}$ tala, od jako kiselih do alkalnih tala. Također je utvrđen njen uspješan rast na različitim 
tipovima tala i tlima različite teksture. Ipak, ova vrsta preferira kultivirana kalcificirana tla (Williams, 1963.). Prema temperaturnim zahtjevima za klijanje sjemena, loboda pripada trećoj skupini u kojoj su korovne vrste koje imaju širok temperaturni raspon za klijanje. Svaki ekotip biljnih (korovnih) vrsta razlikuje se svojim karakteristikama što je povezano s klimatskim područjem u kojem se razvija. Primjerice, za korovnu vrstu Chenopodium album utvrđen biološki minimum potreban za nicanje značajno varira u različitim klimatskim uvjetima, pa prijelazom u toplije klimate biološki minimum ove vrste raste od 2,0 do $6,0^{\circ} \mathrm{C}$ (Vleeshouwers i Kropff, 2000; Wiese i Binning, 1987.). Za područje kontinentalne Hrvatske utvrđen biološki minimum za ovu vrstu je $3,4^{\circ} \mathrm{C}$ (Magosso, 2013.). Ovaj laboratorijski podatak poklapa se i sa stanjem u polju gdje se loboda redovito prva pojavljuje u ranim jarim kulturama (npr. šećerna repa). Optimum za nicanje lobode je između 13 i $30^{\circ} \mathrm{C}$ (Tischler, 1965. cit. prema Kojiću i Šinžaru, 1985.). Primjerice optimalna temperatura za klijanje lobode u Indiji je $10^{\circ} \mathrm{C}$ a u Kanadi $25^{\circ} \mathrm{C}$, što odražava činjenicu da se u umjerenom klimatu Chenopodium album obično ponaša kao ljetni korov dok se u suptropskim zemljama ponaša kao ozima vrsta. Maksimum klijavosti Chenopodium album u Europi dosegne tijekom ožujka i svibnja, te u periodu između kolovoza i listopada (Fryer i Makepeace, 1977.). Prema literaturnim podacima, utvrđeni biološki vodni potencijal, odnosno minimalna količina vode potrebna za nicanje iznosi $-0,80 \mathrm{MPa}$ (Guillemin i sur., 2013.). Slični podaci dobiveni su i $\mathrm{u}$ istraživanjima provedenim na Zavodu za herbologiju Agronomskog fakulteta. Najveća klijavost lobode (oko 70\%) utvrđena je pri vodnom potencijalu do $-0,25 \mathrm{MPa}$. Postupnim povećanjem vodnog stresa, pri $-0,38 \mathrm{MPa}$ klijavost pada na 30\%, dok je najmanja zabilježena klijavost pri $-0,80 \mathrm{MPa}(3 \%)$. Vrijednost biološkog vodnog potencijala sugerira da ova vrsta dobro klije i u uvjetima većeg vodnog stresa. U usporedbi $\mathrm{s}$ drugim okopavinskim korovima, loboda ima veći biološki vodni potencijal od primjerice šcira $(-0,36 \mathrm{MPa})$ i mračnjaka $(-0,67 \mathrm{MPa})$, ali manji od koštana $(-0,97)$ (Šoštarčić, 2015.).

Poznavajući temperaturne zahtjeve za klijanjem i nicanjem korovnih vrsta moguće je prognozirati početak i duljinu trajanja njihovog nicanja te time utjecati na njihovo pravovremeno suzbijanje. Temperatura se smatra najvažnijim klimatskim elementom za predviđanje fizioloških događaja u slučaju da je područje navodnjavano (Russell i sur., 1984; Gadioli i sur., 2000.). Praćenje dinamike nicanja različitih korovnih vrsta u polju bazira se na metodi zbrajanja sume toplinskih jedinica (GDD) gdje je uz dnevne minimalne i maksimalne temperature zraka potrebno poznavati i biološki minimum za svaku korovnu 
vrstu. Temeljem ovih podataka izrađuju se modeli koji pomažu proizvođačima da odaberu najbolju strategiju kontrole korovnih vrsta, a na temelju njihovih ekoloških zahtjeva (Wiles i sur., 1996.). S obzirom na temperaturne zahtjeve razlikuju se tri skupine korovnih vrsta: rano (GDD $<70$ ), srednje (GDD 70 140) i kasno nicajuće vrste (GDD > 140). Prema ovoj podjeli Chenopodium album pripada skupini rano nicajućih korovnih vrsta.

\section{ZAKLJUČAK}

Istraženom literaturom omogućen je uvid u karakteristike korovne vrste Chenopodium album. Treba naglasiti kako se većinom radi o stranoj literaturi, te se navedene vrijednosti, a posebice one koje se tiču biologije i ekologije biljne vrste, trebaju pažljivije interpretirati. Na samom početku skrenuta je pozornost na morfološko-fiziološku raznolikost biotipova te se iz tog razloga ne može tvrditi da bi istraživanja provedena u nekim drugim klimatskim uvjetima dala iste rezultate. U radu je ukazano na široku rasprostranjenost bijele lobode diljem svijeta, kao i na štete koje pričinjava svojom prisutnošću u usjevima.

Iz svega navedenog neupitna je važnost vrste Chenopodium album, a podaci navedeni u ovom radu mogu poslužiti za bolje upoznavanje s ovim opasnim korovom kao i za njegovo uspješno suzbijanje.

\section{LITERATURA}

1. Baker, G. A., O'Dowd, D.J. (1982.): Effects of parent plant density on the production of achene types in the annual Hypochoeris glabra. Journal of ecology 70: 201-215.

2. Barić, K., Ostojić, Z., Šćepanović, M. (2014.): Integrirana zaštita bilja od korova. Glasilo biljne zaštite. 5:416-434.

3. Barić, K., Šćepanović, M. (2015.): Integrirana zaštita šećerne repe od korova. U: Bažok, R., Barić, K., Čačija, M., Drmić, Z., Đermić, E., Gotlin Čuljak, T., Grubišić, D., Ivić, D., Kos, T., Kristek, A., Kristek, S., Lemić, D., Šćepanović, M. i Vončina, D. (2015.). Šećerna repa-Zaštita od štetnih organizama u sustavu integrirane biljne proizvodnje. Sveučilište u Zagrebu, Agronomski fakultet. $96-112$.

4. Basset, I. J., Crompton, C.W. (1978.): The biology of Canadian weeds. 32. Chenopodium album L. Can. J. Plant Sci. 58:1061-1072.

5. Benvenuti, S., Macchia, M., Miele, S. (2001.): Quantitative analysis of emergence of seedlings from buried weed seeds with increasing soil depth. Weed Science, 49(4):528-535. 
6. Bhowmik, P. C., Doll, J. D. (1980.): Field studies on allelopathic effects of weed and crop residues. Proceedings North Central Weed Control Conference., Volume 35:82-83

7. Bhowmik, P. C., (1982.): Allelopathic activity of annual weeds on corn (Zea mays) and soybeans (Glycine max). Dissertation Abstracts International, B, 42(7):2637.

8. Buck, W. M., Preston, K. S., Abel, M. and Marshall, M. S. (1966.): Perirenal edema in swine: a disease caused by common weeds. Amer. Vet. Med. Assoc. J. 148: 1525-1531.

9. Coquillat, M. (1951.): Sur les plantes les plus communes a' la surface du globe. Bulletin Mensuel de la Societe Linneenne de Lyon, 20:165-170.

10. Cumming, B. G. (1963.): The dependence of germination on photoperiod, light quality and temperature in Chenopodium spp. Can. J. Bot. 41: 1211-1233.

11. Dowson, J. H. (1965.). Competition between irrigated sugarbeets and annual weeds. Weeds 13., 245-249.

12. Everist, S. L. (1979.): Poisonous plants of Australia, 2nd ed. Angus \& Robertson Publ. London.

13. Flegar, Z., Ostojić, Z. (1993.): Rezistentnost korova na herbicide. Fragmenta phytomedica et herbologica. 21: 83-97.

14. Fryer, J. D., Makepeace, R. J. (1977.): Weed control handbook. Volume I. Principles, including plant growth regulators. Blackwell Scientific Publications. Oxford UK, Ed. 6:xvii + 510 pp.

15. Gadioli, J. L., Dourado-Neto, D., Garcia, A. G., Basanta, M. (2000.): Temperatura do ar, rendimento de grãos de milho e caracterização fenológica associada à soma calórica. Sci. Agric., 57: 377-383.

16. Gudin, C., Syratt, W. J.,Boize, L. (1976.): The mechanisms of photosynthetic inhibition and the development of scorch in tomato plants treated with spray oils. Ann. Appl. Biol. 84:213-219.

17. Guillemin, J. P., Gardarin, A., Garanger, S., Reibel, C., Munier-Jolain, N., Colbach, N. (2013.): Assessing potential germination period of weed with base temperatures and base water potentials. Weed Research. 53, 76 - 87.

18. Hagood, E. S. Jr. (1989.): Control of triazine-resistant smooth pigweed (Amaranthus hybridus) and common lambsquarters (Chenopodium album) in no-till corn (Zea mays). Weed Technology, 3(1):136-142.

19. Harper, J. L., Williams, J. T., Sagar, G. R. (1965.): The behaviour of seeds in soil. I. The heterogeneity of soil surfaces and its role in determining the establishment of plants seed. J. Ecol. 53:273-286. 
20. Hess, F. D. (1985.): Herbicide absorption and translocation and their relationship to plant tolerances and susceptibility. S. O. Duke, ed. Weed Physiology. Volume II. Herbicide Physiology. Boca Raton, FL: CRC. 191-214.

21. Holm, LG, Plucknett, DL, Pancho, JV, Herberger, JP. (1977.): The World's Worst Weeds. Distribution and Biology. Honolulu, Hawaii, USA: University Press of Hawaii. 21 - 43.

22. Jansen, PCM. (2004.): Chenopodium album L., Grubben GJH, Denton OA, eds. Vegetables. Plant Resources of Tropical Africa (PROTA) 2:178-180.

23. Jellen, E.N., Kolano, B.A., Sederberg, M.C., Bonifacio, A., Maughan, P.J. (2011.) Chenopodium. In: Kole C. (eds) Wild Crop Relatives: Genomic and Breeding Resources. Springer, Berlin, Heidelberg. $35-61$.

24. Kojić, M. i Šinžar, B. (1985.): Korovi, Naučna knjiga Beograd.

25. Kojić, M. (1981.): Određivanje korova u stadijumu klijanaca i njihovo suzbijanje herbicidima, Nolit, Beograd, 57-58.

26. Konstantinović, B., Blagojević, M., Smardžić, N. (2015.): Resistence of weed species Chenopodium album L. to ALS-inhibitors. Romanian Agricultural Research 32:253-261.

27. Korsmo, E, Torstein, V, Fykse, H. (1981.): Korsmos' Ugras Plansjer. Oslo, Norway: Norsk Landbruk/Landbruks Forlaget.

28. Kovačić, I. (2013.): Klijavost sjemena Chenopodium album pri različitim dubinama u tlu. Završni rad, Sveučilište u Zagrebu Agronomski fakultet. $11-13$.

29. Kropff, M. J., Spitters, C. J. T. (1991.): A simple model of crop loss by weed competition from early observations on relative leaf area of the weeds. Weed Research 31 (2):97-105

30. Kropff, M. J., Weaver, S. E., Smits, M. A. (1992.): Use of ecophysiological models for crop-weed interference: relations amongst weed density, relative time of weed emergence, relative leaf area, and yield loss. Weed Science, 40 (2):296-301.

31. Lemić, M., Šćepanović, M., Barić, K., Svečnjak, Z., Jukić, Ž. (2014.): Metode prekidanja dormantnosti sjemena bijele lobode (Chenopodium album L.). Agronomski glasnik, 1-2: 45-60.

32. Lowell, S.T., Wax, L.M., Horak, M.J., Peterson, D.E. (1996.): Imidazolinone and Sulfonylurea Resistance in a Biotype of Common Waterhemp. Weed Science, 44: 789-794. 
Ema Brijačak i sur.: Biologija i ekologija bijele lobode (Chenopodium album L.)

33. Magosso, D. (2013.): Study of germination parameters of summer weeds: transferability of AlertInf model to Croatia. Master thesis, University of Padova.

34. Mandal, R. C. (1990.): Weeds, weedicides and weed control - principle and practice. Bikaner, India: Agro Botanical Publishers.

35. McWhorter, C. G. (1993.): Epicuticular wax on johnsongrass (Sorghum halepense) leaves. Weed Sci. 41:475-482.

36. Ngouajio, M, Lemieux, C, Leroux, GD. (1999.): Prediction of corn (Zea mays) yield loss from early observations of the relative leaf area and the relative leaf cover of weeds. Weed Science, 47(3):297-304.

37. Nikolić, T. (2013.): Sistematska botanika. Raznolikost i evolucija biljnog svijeta. Alfa Zagreb. 551-556.

38. Ostojić, Z., Zadro, J., Radiković, Đ. (1983.): Rezistentnost Chenopodium album L. na atrazin. Interno izvješće Instituta za zaštitu bilja, Zagreb.

39. Ostojić, Z., Zadro, J., Radiković, Đ. (1991.): Naši napasni korovi: Obična loboda Chenopodium album (L). Glasnik zaštite bilja 10:317-322.

40. Ostojić, Z. (2011.): The changes of the composition of weed flora in southeastern and central europe as affected by cropping practices - Croatia. U Šarić T., Ostojić Z., Stefanović L., Deneva Milanova S., The changes of the composition of weed flora in southeastern and central europe as affected by cropping practices. Herbologia 12: 8-12.

41. Ostojić, Z., Barić, K. (2017.): Povijest istraživanja rezistentnost korova na herbicide u Hrvatskoj, Glasilo biljne zaštite 5:500-505.

42. Raunkiaer, C. (1905.): Types biologiques pour la géographie botanique. (Kgl. Danskevidenskabeernes sclskabs Forhandt, 5, 347-437). Bull. Acad. R. Sc. Danemark, 347-437.

43. Reinhardt, C. F., Meissner, R, Labuschagne, N. (1994.): Allelopathic interaction between Chenopodium album L. and certain crop species. South African Journal of Plant and Soil, 11(1):45-49.

44. Russell, M. P., Wilhelm W., Olson, R. A., Power, J. F.. (1984.): Growth analysis based on degree days. Crop Sci. 24: 28-32.

45. Schweizer, E. E., Zimdahl, R.L. (1984.): Weed seed decline in irrigated soil after six years of continous corn (Zea mays) and herbicides. Weed Sci. 32: 76-83.

46. Shurtleff, J. L., Coble, H. D. (1985.): Interference of certain broadleaf weed species in soybeans (Glycine max). Weed Science, 33(5):654-657. 
47. Sibuga, K. P., Bandeen, J. D. (1980.): Effects of green foxtail and lamb'squarters interference in field corn. Canadian Journal of Plant Science, 60(4):1419-1425.

48. Solymosi, P, Lehoczki, E, Laskay, G. (1986.): Difference in herbicide resistance to various taxonomic populations of common lambsquarters (Chenopodium album) and late-flowering goosefoot (Chenopodium strictum) in Hungary. Weed Science, 34(2):175-180.

49. Šera, B., Šery, M., Štranak, V., Špatenka, P., Tichy, M. (2009.): Does cold plasma affect breaking dormancy and seed germination? A study on seeds of Lamb's Quarters (Chenopodium album agg.). Plasma science and technology, Vol. 11, No. 6. $750-754$.

50. Šoštarčić, V. (2015.): Biološki parametri toploljubivih korovnih vrsta: transfer AlertInf modela iz Italije u Hrvatsku. Rektorova nagrada. Sveučilište u Zagrebu Agronomski fakultet. 24-28.

51. Šulek, B. (1879.): Jugoslavenski imenik bilja. Tiskom dioničke tiskare. Hrvatsko Sveučilište. 507 - 508.

52. Tischler, W. (1965.): Agrarökologie. VEB G. Fischer, Jena, 499 pp.

53. Torner, C, Sanchez, MJ, Pardo, A, Suso, ML, Caudevilla, ME, Zaragoza, C. (1995): Growth evolution of maize in competition with Chenopodium album and Datura stramonium. U: Brown H, Cussans GW, Devine MD; Duke SO, Fernandez-Quintanilla C, Helweg A, Labrada RE, Landes M, Kudsk P, Streibig JCP, eds. Proceedings of the Second International Weed Control Congress, Copenhagen, Denmark. Slagelse, Denmark: Department of Weed Control and Pesticide Ecology, 215-219.

54. Uchytil, R., J. (1992.): Eragrostis lehmanniana. U: Fire Effects Information System, U.S. Department of Agriculture, Forest Service, Rocky Mountain Research Station, Fire Sciences Laboratory.

55. Vleeshouwers, L. M., Kropff, M. J. (2000.): Modelling field emergence patterns in arable weeds. New Phytol. 148: 445 - 457.

56. Wiese, A. M., Binning, L. K. (1987.): Calculating the threshold temperature of development for weeds. Weed Science 35: $177-179$.

57. Wiles, L. J., King, R. P., Schweizer, E. E., Lybecker, D. W. i Swinton, S. M. (1996.): GWM: General Weed Management model. Agric. Syst. 50: 355-376

58. Williams, J. T. (1963.): Biological flora of the British Isles: Chenopodium album L. J. Ecol. 51:7 11-725.

59. Wodehouse, R. P. (1971.): Hayfever Plants. New York, USA: Hafner Publishing Company. 
60. Wright, R. H. (1972.): What good is a weed? Ecology in Action. Lothrop, Lee \& Shepard Co., New York.

http://www.discoverlife.org/mp/20m?kind=Chenopodium+album, pristupljeno 16. siječnja 2018. godine

http://www.agroatlas.ru/en/content/weeds/Chenopodium_album/, pristupljeno 29. lipnja 2018. godine

http://www.weedscience.org/Resistance/resistmodule.asp., pristupljeno 16. siječanj 2018. godine

http://www.onlyfoods.net/chenopodium-album.html, pristupljeno 16. siječanj 2018. godine

http://www.soilcropandmore.info/crops/Weeds/UvaldeWeedSite/final/chal_fl.jpg, pristupljeno 16. siječanj 2018. godine

Adrese autora - Author's address:

Ema Brijačak,

Studentica diplomskog studija Fitomedicina

Sveučilište u Zagrebu, Agronomski fakultet

Valentina Šoštarčić,

Maja Šćepanović, e-mail: mscepanovic@agr.hr

Sveučilište u Zagrebu, Agronomski fakultet, Zavod za herbologiju
Primljeno-received:

28.02.2018. 